\title{
DOSSIER
}

\section{L'ÉCOLE ET LES MALADIES DANS LE MONDE (XIXE-XXE SIÈCLES)}

\author{
Séverine Parayre \\ Institut Catholique de Paris, Faculté d'Éducation, France \\ severineparayre@gmail.com \\ Lucia Martinez Moctezuma \\ Instituto de Ciencias de la Educación \\ Universidad Autónoma del Estado de Morelos, México \\ luciamm@uaem.mx
}

\section{Introduction de rédactrice invitée}

Nous nous intéresserons au corps malade et aux maux du corps, à leurs prises en charge au sein du système éducatif et aux transformations induites dans les conceptions et pratiques scolaires. Au cours des XIXe et XXe siècles, différentes maladies et épidémies ont frappé les sociétés, qui, souvent démunies, ont été amenées à instaurer des stratégies préventives et curatives. Le système éducatif a été sollicité de nombreuses fois par le milieu médical pour répondre aux états d'urgence sanitaire et a dû s'adapter aux conditions et possibilités qui s'offraient à lui. L'Ecole est devenue ainsi au fur et à mesure de son développement, non seulement un lieu à fort risque de propagation des maladies, mais aussi un lieu qui crée des maladies et peut détériorer les corps ${ }^{1}$. Durant la seconde moitié du XIXe siècle, certains maux sont alors décrétés comme purement des "maladies scolaires", c'est l'exemple caractéristique des déformations de la colonne vertébrale, de la myopie ou encore de la fatigue intellectuelle et du surmenage ${ }^{2}$.

Cette problématique des maladies à l'École et de l'École se généralise aux XIXe et XXe siècles à l'ensemble des pays. Certains s'influencent et répondent de façon identique à leurs traitements organisant une gestion stricte de tout corps déviant de la norme scolaire ${ }^{3}$. Nombreux médecins dans tous les pays à la fin du XIXe siècle se sont penchés sur ces problèmes scolaires et ont fini par apporter des transformations aux pédagogies et aux rythmes scolaires, notamment sur les manières d'écrire, de lire, de s'asseoir, de manger etc. ${ }^{4}$.

\footnotetext{
${ }^{1}$ RIANT, A. Hygiène scolaire, influence de l'école sur la santé des enfants. Paris: Hachette, 1874.

${ }^{2}$ LABIT, H. J. et POLIN, L. H. L'hygiène scolaire tome II les maladies scolaires. Paris: Carré et Naud, 1896.

${ }^{3}$ FOUCAULT, M. Histoire de la sexualité, t I la volonté de savoir. Paris: tel Gallimard; Vigarello, G. (2004, nelle éd.). Le corps redressé. Histoire d'un pouvoir pédagogique. Paris: A. Colin, 1994.

${ }^{4}$ RUIZ, L. E. Cartilla de Higiene. México: Librería de la Vda, de Bouret, 1902.
} 
Or l'histoire des maladies à l'École, de leurs gestions et influences pédagogiques est peu développée dans le monde. C'est pour cela que nous proposons de latraiter en deux axes principaux avec plusieurs questions.

Le premier axe est celui des maladies à l'École, celles venant de l'extérieur et pouvant se propager à l'intérieur de l'École. Quelles sont celles qui font l'objet sur les différents territoires de prises de précautions en milieu scolaire et quelles sont les mesures et actions mis en place? Quels acteurs sont impliqués, et quels partenariats se créent entre eux? En la matière les actions des médecins ont parfois été négligées dans l'historiographie, mais aussi les stratégies des enseignant-e-s et du personnel éducatif pour favoriser un avenir meilleur et le bien-être scolaire. Ainsi sera abordée de quelle manière la gestion des maladies et de la mort dans l'enceinte scolaire aurait pu modifier les conceptions et rapports au corps et les pédagogies. Les préceptes généraux de médicalisation seront-ils suivis ou d'autres pratiques curatives et préventives vont-elles être favorisées?

Le second axe est celui des maladies de l'École, celles induites et causées par l'École et le système scolaire. Quelles sont ces maladies spécifiques et de quelle manière sont-elles appréhendées? Est-ce-que ces nouvelles maladies induisent des changements durables au sein du système scolaire, des pédagogies et des pratiques? Les enseignant-e-s y répondent-ils (elles) différemment selon les catégories sociales, les lieux (campagnes, urbains), les niveaux scolaires (primaire, secondaire, supérieur), les sexes?

Nous rapprocherons nos deux axes de manière à mieux comprendre comment se sont dessinés dans l'enceinte scolaire les soins et préventions, les partenariats et pédagogies autour de la gestion des corps et du développement de la médicalisation dans l'École et par l'École 5 .

En prenant le cas de pays comme la Colombie, le Brésil, le Mexique, l'Espagne et la France dans la préparation des articles de ce dossier, différentes sources d'information ont été utilisées: enquêtes auprès des enseignants, des rapports des inspecteurs, des enseignants et des médecins qui viennent des archives et des bibliothèques: les Archives Nationales et les Archives Alfred Binet en France, les Archives historiques du Ministère de l'Éduation Publique au Mexique ou les Archives de la Faculté de Médecine de l'Université Nationale de Colombie. Certains manuels sont des collections particulières, mais d'autres font partie du patrimoine historique de l'ancienne École Normale de Campinas (Brésil). Des photographies et des films qui sont dans la Fototeca Digital delInstitutoNacional de Antropología e Historia

${ }^{5}$ FEE, E. and ACHESON, R. M. (dir.). A History of education in public health. Oxford, New York: Oxford University Press, 1991. 
(INAH) au Mexique et dans la Filmoteca Española de Valencia (IVAC) y de Catalunya, ainsi que des affiches utiles au cours de la période fasciste en Espagne sont également utilisés.

L'utilisation de ces sources révèle non seulement la qualité de celles-ci, mais le travail du chercheur de systématiser l'information pour servir á son propos. Comme dans le cas de l'enquête-concours promu parmi les enseignants en milieu rural par le Ministère de l'Education de la France en 1860; les documents d Alfred Binet qui montrent la mesure de l'intelligence chez l'élève; l'analyse des films, pour le cas espagnol ou des photos pour le cas du Mexique; la lecture de textes étrangers dans l'École Normale de Campinas et d'autres documents qui représentent un défi pour le chercheur..

Des documents originaux et riches placés dans des différents archives et bibliothèques qui permettent de nous rapprocher au corps de l'étudiant, l'enseignant et la communauté rurale à travers des discours et des représentations qui font partie de mouvements plus larges comme l'hygiéniste, l'eugénisme, le fascisme, à travers des campagnes vaccination, leçons de Psychologie et de l'anthropologie pédagogique pratiqué l'école normale de São Paulo, dans le domaine de la éducation physique, le sport et le loisirs en France ou Mexique.

\section{ESCUELA Y ENFERMEDADES EN EL MUNDO (SIGLOS XIX Y XX)}

\section{Introducción de editor invitado}

Nos interesamos en el cuerpo enfermo y en las enfermedades del cuerpo, en su cuidado en el seno del sistema educativo y en los cambios producidos a partir de las concepciones y prácticas escolares. Durante los siglos XIX y XX, diferentes enfermedades y epidemias afectaron a las sociedades, que, a menudo desprovistas, fueron confrontadas a implementar una serie de estrategias preventivas y curativas. La comunidad médica recurrió al sistema educativo para atender las emergencias sanitarias y tuvo que adaptarse a las condiciones y las posibilidades que se le ofrecieron. La escuelas e convirtió progresivamente, no solamente en un lugar en el que se propagaban las enfermedades, sino también donde se originaban las enfermedades que podían dañar el cuerpo ${ }^{6}$. Durante la segunda mitad del siglo XIX, algunos males fueron clasificados típicamente como "enfermedades de la escuela";

\footnotetext{
${ }^{6}$ RIANT, A. Hygiène scolaire, influence de l'école sur la santé des enfants. Paris: Hachette, 1874.
} 
como en el caso de la deformación de la columna vertebral, la miopía, la fatiga intelectual y el surmenage ${ }^{7}$.

Esta problemática de las enfermedades en la escuela y de la escuela se generaliza en casi todos los países, en el curso de los siglos XIX y XX. Algunas se inspiran y responden de forma similar a sus tratamientos organizando una vigilancia estricta sobre cualquier cuerpo que se desvía de la norma escolar ${ }^{8}$. A finales del siglo XIX, muchos médicos se ocupan de estos problemas en la escuela proponiendo cambios en las pedagogías y en los ritmos escolares, en particular sobre la forma de escribir, leer, sentarse, comer, etc. ${ }^{9}$.

Pero la historia de las enfermedades en la escuela, sus gestiones e influencias pedagógicas ha sido poco desarrollada en el mundo. Por esto nos hemos propuesto organizar un dossier para abordar el problema desde dos ejes principales haciéndonos varias preguntas.

El primer eje es el de las enfermedades en la Escuela, las que vienen del exterior y pueden propagarse al interior de la Escuela. ¿Cuáles son las que surgen en determinados territorios y cuáles las medidas y las acciones que se toman? ¿Que actores están implicados y que compromisos se crean entre ellos? En este terreno las acciones de los médicos y de otros profesionales de la salud han sido desestimadas por la historiografía, tanto como las estrategias de los/las profesoras y del personal educativo para favorecer un mejor avenir y el bienestar escolar. Así, nos preocuparemos también por conocer de qué manera la gestión de la enfermedad y la muerte, en el entorno escolar, habría podido modificar las concepciones y las relaciones con el cuerpo y sus pedagogías. Los preceptos generales de medicalización serían cumplidos o fueron favorecidas otras practicas curativas y preventivas?

El segundo eje es el de las enfermedades de la Escuela, inducidas y causadas por la Escuela y por el funcionamiento del sistema escolar. ¿Cuáles son las enfermedades específicas y de qué manera son aprehendidas?, ¿Es que las nuevas enfermedades inducen a cambios que perduran dentro del sistema escolar, las pedagogías y las prácticas? Los/las profesoras responden de manera diferenciada dependiendo de la categoría social, el lugar (el campo, la ciudad), los niveles escolares (primaria, secundaria, superior), los géneros?

Recurriremos a nuestros dos ejes para tratar de comprender mejor cómo fueron diseñadas y puestas en práctica por diversos actores (profesores, inspectores, enfermeras, médicos), en el entorno escolar, la atención y la prevención, las asociaciones y las pedagogías

\footnotetext{
${ }^{7}$ LABIT, H. J. et POLIN, L. H. L'hygiène scolaire tome II les maladies scolaires. Paris: Carré et Naud, 1896. ${ }^{8}$ FOUCAULT, M. Histoire de la sexualité, t I la volonté de savoir. Paris: tel Gallimard; Vigarello, G. (2004, nelle éd.). Le corps redressé. Histoire d'un pouvoir pédagogique. Paris: A. Colin, 1994.

${ }^{9}$ RUIZ, L. E. Cartilla de Higiene. México: Librería de la Vda, de Bouret, 1902.
} 
al rededor de la gestión de los cuerpos y del desarrollo de la medicalización en la Escuela y para la Escuela ${ }^{10}$.

Tomando el caso de países como Colombia, Brasil, México, España y Francia en la elaboración de los artículos que componen este dossier, se utilizaron diferentes fuentes de información: encuestas a profesores, informes de inspectores, profesores y médicos que provienen de archivos y bibliotecas como los Archivos Nacionales y el Archivo Alfred Binet en Francia, el Archivo Histórico de la Secretaría de Educación Pública en México o el Archivo de la Facultad de Medicina de la Universidad Nacional en Colombia. Algunos libros de texto son de propiedad particular pero otros forman parte del patrimonio histórico educativo de la antigua Escuela Normal de Campinas (Brasil). También se utilizan fotografías y filmes que se encuentran en la Fototeca Digital del Instituto Nacional de Antropología e Historia (INAH) en México así como la Filmoteca Española de Valencia (IVAC) y de Catalunya, así como carteles útiles durante el periodo fascista en España.

El uso de estas fuentes muestra no sólo la calidad de éstas sino el trabajo del investigador por sistematizar la información para servir a un objetivo. Como en el caso de la encuesta-concurso promovida entre los profesores rurales por el ministerio de Instrucción Pública de Francia en 1860; los papeles de Alfred Binet que dan muestra de la medición de la inteligencia en el alumno; el analisis de los filmes, para el caso español o de la fotografías para el caso mexicano; la lectura de textos extranjeros en la Escuela Normal de Campinas y otros documentos que representan un reto para el investigador.

Documentos originales y ricos conservados en diferentes repositorios que nos permiten acercarnos al cuerpo del estudiante, del profesor y de la comunidad rural a través de discursos y representaciones que se inscriben en movimientos amplios como el higienista, la eugenesia, el fascismo, a través de campañas de vacunación, lecciones de Psychologia y Antropología pedagógica practicadas la Escuela Normal de São Paulo, en el campo de las actvidades físicas, deportivas y de entretenimiento corporal en Francia o en México.

\section{SCHOOL AND DISEASES IN THE WORLD (XIX-XX CENTURIES)}

\section{Guest Editor's Introduction}

\footnotetext{
${ }^{10}$ FEE, E. and ACHESON, R. M. (dir.). A History of education in public health. Oxford, New York: Oxford University Press, 1991.
} 
We are interested in the sick body and the diseases associated to it, as well as its care in the frame of the education system and changes produced based on conceptions and scholastic practices.

During the XIXth and XXth centuries, different sicknesses and epidemics affected societies, which, usually unprepared, were confronted with implementing a series of preventive and healing strategies. The medical community turned to the education systems to attend to sanitaria emergencies and had to adapt to the conditions and possibilities offered to it. Schools progressively became not only places where illnesses propagated, but also where illnesses that could harm the body originated ${ }^{11}$. During the second half of the XIX century, some illnesses were typically classified as "school diseases," such as deformation of the spine, myopia, intellectual fatigue, and overwork ${ }^{12}$.

This predicament of diseases in school and school diseases is generalized in almost all countries during the XIXth and XXth centuries. Some are inspired and respond similarly to their treatment by organizing strict vigilance on anybody that deviates from the school norm ${ }^{13}$. Towards the end of the XIXth century, many doctors took care of these problems in school by proposing changes in pedagogies and school rhythms, in particular in the way of writing, reading, sitting, eating, etc. ${ }^{14}$.

However, the history of diseases in school, its management and pedagogical influences has been little developed in the world. That is why we set out to organize a dossier that addresses the problem from two main axes and with several issues.

The first axis focuses on diseases that come from the outside and can be propagated within the school. Which emerged in a given territory and what measures and actions were taken? Which actors were implicated and what commitments were created among them? In this terrain, actions of doctors and of other health professionals have been disregarded in historiography, as well as the strategies of teachers and education personnel to favor a better future and school wellbeing. We are also interested in knowing how the management of disease and death within the school could have modified conceptions and relations with the body and pedagogy. Were the general precepts of medication complied with or favored, given other healing and preventing practices?

\footnotetext{
${ }^{11}$ RIANT, A. Hygiène scolaire, influence de l'école sur la santé des enfants. Paris: Hachette, 1874.

${ }^{12}$ LABIT,H.J. et POLIN,L. H. L'hygiène scolaire tome II les maladies scolaires. Paris: Carré et Naud, 1896.

${ }^{13}$ FOUCAULT, M. Histoire de la sexualité, t I la volonté de savoir. Paris: tel Gallimard; Vigarello, G. (2004, nelle éd.). Le corps redressé. Histoire d'un pouvoir pédagogique. Paris: A. Colin, 1994.

${ }^{14}$ RUIZ,L. E. Cartilla de Higiene. México: Librería de la Vda, de Bouret, 1902.
} 
The second axis regards "school diseases", those induced and caused by school and due to the structure of the scholastic system. Which were the specific diseases and how were they understood? Did the new diseases induce changes that lasted within the school system, pedagogies, and practices? Did the teachers respond differently depending on the social category, place (rural or urban), and school levels (elementary, middle, and high), genders?

We will use our two axes to try to understand better how they were designed and implemented by different actors (teachers, inspectors, nurses, doctors), in the school environment, in care and prevention, the associations and pedagogies surrounding the management of bodies and the development of medication in school and for school ${ }^{15}$.

In the case of countries such as Colombia, Brazil, Mexico, Spain and France, different sources of information were used in the elaboration of the articles that compose this dossier: surveys for teachers, reports by inspectors, teachers and doctors coming from archives and libraries such as the National Archives and the Alfred Binet Archive in France, the Historical Archive of the Secretariat of Public Education in Mexico, and the Archive of the Faculty of Medicine of the National University in Colombia. Some textbooks are privately owned but others are part of the historical educational heritage of the former Normal School of Campinas (Brazil). Also used are photographs and films found in the Digital Photo Library of the National Institute of Anthropology and History (INAH) in Mexico as well as the Spanish Film Archive of Valencia (IVAC) and of Catalonia, as well as useful posters during the fascist period in Spain.

The use of these sources reveals not only their quality but the work of the researcher to systematize the information to serve a goal. As it is the case for the survey-contest promoted among the rural teachers by the Ministry of Public Instruction of France in 1860; the papers of Alfred Binet that give sample of the measurement of the intelligence in the student; the analysis of the films, for the Spanish case, or the photographs for the Mexican case; the reading of foreign texts in the Normal School of Campinas, and other documents that represent a challenge for the researcher.

Original and rich documents preserved in different repositories allow us to approach the body of the student, the teacher and the rural community through speeches and representations that are inscribed in broad movements such as the hygienist, eugenics, fascism, through campaigns of vaccination, lessons of psychology and pedagogical

\footnotetext{
${ }^{15}$ FEE,E. and ACHESON,R. M. (dir.). A History of education in public health.Oxford, New York: Oxford UniversityPress, 1991.
} 
anthropology practiced in the Normal School of São Paulo, in the field of physical activities, sports and body entertainment in France or Mexico.

\section{ESCOLA E DOENÇAS NO MUNDO (SÉCULOS XIX E XX)}

\section{Apresentação}

Nos interessamos pelo corpo doente e as doenças a ele associadas, bem como ao seu cuidado no seio do sistema educativo e mudanças produzidas a partir de concepções e práticas escolares. Durante os séculos XIX y XX, diferentes doenças e epidemias afetaram as sociedades que, desprovidas, foram chamadas a implementar una série de estratégias preventivas e curativas. A comunidade médica voltou-se para o sistema educativo para atender emergências sanitárias e teve que adaptar-se às condições e às possibilidades que se apresentavam. A escola se converteu, progressivamente, não somente em lugar de propagação de doenças, mas também local em que se originavam doenças que podiam atacar o corpo ${ }^{16}$. Durante a segunda metade do século XIX, alguns males foram clasificados tipicamente como "doenças da escola"; como no caso da deformação da coluna vertebral, da miopia, da fadiga intelectual e do excesso de trabalho ${ }^{17}$.

Esta problemática das doenças na escola e da escola é generalizada em quase todos os países, durante os séculos XIX e XX. Algumas se inspiram e respondem de forma similar aos seus tratamentos organizando uma vigilancia estrita sobre qualquer corpo que se desvia da norma escolar ${ }^{18}$. Em finais do siglo XIX, muitos médicos se ocuparam destes problemas na escola propondo mudanças nas metodologías e nos ritmos da escola, em particular, sobre a forma de escrever, ler, sentar-se, comer, etc. ${ }^{19}$.

Entretanto, a história das doenças na escola, sua gestão e influências pedagógicas tem sido pouco desenvolvida no mundo. Por isso nos propusemos a organizar um dossiê que abordasse o problema a partir de dois eixos principais e com várias questões.

O primeiro eixo é o das doenças na Escola, aquelas que vêm de fora e podem se propagar para o interior da Escola. Quais são aquelas que surgem em determinados territórios e quais medidas e ações implementadas? Quais atores estão implicados e os compromisos que

\footnotetext{
${ }^{16}$ RIANT, A. Hygiène scolaire, influence de l'école sur la santé des enfants.Paris: Hachette, 1874.

${ }^{17}$ LABIT, H. J. et POLIN, L. H. L’hygiène scolaire tome II les maladies scolaires. Paris: Carré et Naud, 1896.

${ }^{18}$ FOUCAULT, M. Histoire de la sexualité, t I la volonté de savoir. Paris: tel Gallimard; Vigarello, G. (2004, nelle éd.). Le corps redressé. Histoire d'un pouvoir pédagogique. Paris: A. Colin, 1994.

${ }^{19}$ RUIZ, L. E. Cartilla de Higiene. México: Librería de la Vda, de Bouret, 1902.
} 
se criam entre eles? Nesse terreno, as ações dos médicos e outros profissionais da saúde têm sido negligenciadas pela historiografía, tanto como as estratégias dos (as) profesores e demais sujeitos da educação para favorecer um futuro melhor e o bem estar escolar. Assim, nos preocuparemos também em conhecer de que maneira a gestão da doença e da morte, no entorno escolar, poderia modificar as concepções e as relações com o corpo e suas pedagogias? Os preceitos gerais de medicalização seriam cumpridos ou foram favorecidas outras práticas curativas e preventivas?

O segundo eixo é o das doenças da Escola, induzidas e causadas pela Escola e pelo funcionamento do sistema escolar. Quais são as doenças específicas e de que maneira são apreendidas? As novas doenças induzem a mudanças duráveis no seio do sistema escolar, das pedagogias e das práticas? Os/As professores(as) respondem de maneira diferenciada dependendo da categoria social, o lugar (o campo, a cidade), os níveis escolares (fundamental, médio, superior), os gêneros?

Recorreremos aos nossos dois eixos para compreender melhor como foram desenhadas e colocadas em prática por diversos atores (professores, inspetores, enfermeiras, médicos), no ambiente escolar, a atenção e a prevenção, asassociações e as pedagogías ao redor da gestão dos corpos e do desenvolvimento da medicalização na escola e para a escola $^{20}$.

Tomando o caso de países como Colômbia, Brasil, México, Espanha e França na elaboração dos artigos que compõem este dossiê, foram utilizadas diferentes fontes de informação: entrevistas com professores, relatórios de inspetores, professores e médicos advindos de arquivos e bibliotecas como os Arquivos Nacionais e o Arquivo Alfred Binet na França, o Arquivo Histórico da Secretaria da Educação Pública no México ou o Arquivo da Faculdade de Medicina da Universidade Nacional da Colômbia. Alguns livros de texto são de propriedade particular, mas outros fazem parte do patrimônio histórico educativo da antiga Escola Normal de Campinas (Brasil). Também se utilizam fotografías e filmes que se encontram na Filmoteca Digital do Instituto Nacional de Antropologia e História (INAH) no México, assim como na Filmoteca Espanhola de Valência (IVAC) e da Catalunha, como também cartazes úteis durante o período fascista na España.

O uso das fontes revela não somente a importância das mesmas, mas também o trabalho do pesquisador em sistematizar a informação para servir a um objetivo. Como foi o caso do concurso de pesquisa promovido entre os profesores rurais pelo Ministério da

\footnotetext{
${ }^{20}$ FEE, E. and ACHESON, R. M. (dir.).A History of education in public health. Oxford, New York: Oxford University Press, 1991.
} 
Instrução Pública da França, em 1860; os papéis de Alfred Binet que dão a mostra da medida da inteligência no aluno; a análise dos filmes, para o caso espanhol, ou as fotografias para o caso mexicano; a leitura de textos estrangeiros na Escola Normal de Campinas e outros documentos que representam um desafio para o pesquisador. Documentos originais e ricos conservados em diferentes repositórios que nos permitem a aproximação ao corpo do estudante, do profesor e da comunidade rural através de discursos e representações advindos de movimentos maiores como o higienismo, o eugenismo, o fascismo, as campanhas de vacinação, lições de Psicologia e Antropologia pedagógica praticadas na Escola Normal de São Paulo, no campo das atividades físicas, desportivas e de entretenimento corporal na França e no México. 